\title{
DEVELOPMENT OF A PLANT-SCALE RESIN
} CALCINATION SYSTEM FOR PREPARING TRANSPLUTONIUM OXIDES OR OXYSULFATES

\author{
R. F. BRADLEY \\ G. A. BURNEY
}

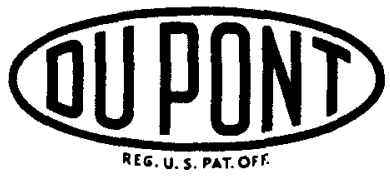

Savannah River Laboratory

Aiken, South Carolina 


\section{NOTICE}

This report was prepared as an account of work sponsored by the United States Government. Neither the United States nor the United States Atomic Energy Commission, nor any of their employees, nor any of their contractors, subcontractors, or their employees, makes any warranty, express or implied, or assumes any legal liability or responsibility for the accuracy, completeness or usefulness of any information, apparatus, product or process disclosed, or represents that its use would not infringe privately owned rights.

Printed in the United States of America

Available from

National Technical Information Service

U. S. Department of Commerce 5285 Port Royal Road

Springfield, Virginia 22151

Price: Printed Copy $\$ 3.00$; Microfiche $\$ 0.95$ 


\section{DISCLAIMER}

This report was prepared as an account of work sponsored by an agency of the United States Government. Neither the United States Government nor any agency Thereof, nor any of their employees, makes any warranty, express or implied, or assumes any legal liability or responsibility for the accuracy, completeness, or usefulness of any information, apparatus, product, or process disclosed, or represents that its use would not infringe privately owned rights. Reference herein to any specific commercial product, process, or service by trade name, trademark, manufacturer, or otherwise does not necessarily constitute or imply its endorsement, recommendation, or favoring by the United States Government or any agency thereof. The views and opinions of authors expressed herein do not necessarily state or reflect those of the United States Government or any agency thereof. 


\section{DISCLAIMER}

Portions of this document may be illegible in electronic image products. Images are produced from the best available original document. 
R. F. Bradley

G. A. Burney

\section{Approved by}

A. S. Jennings, Research Manager Separations Engineering Division and

J. A. Porter, Research Manager Separations Chemistry Division

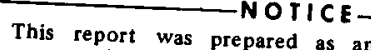

\section{E. I. DU PONT DE NEMOURS \& COMPANY SAVANNAH RIVER LABORATORY}

AIKEN, S. C. 29801

CONTRACT AT(07.2).1 WITH THE

UNITED STATES ATOMIC ENERGY COMMISSION 


\section{ABSTRACT}

A plant-scale system was developed to prepare $100 \mathrm{mg}$ batches of californium-252, or other transplutonium isotopes, as the oxysulfate or oxide without directly handling small quantities of liquid or solid. The californium is sorbed on $250 \mathrm{~cm}^{3}$ of cation exchange resin in a platinum column, the resin is burned away, and the column is heated to form oxysulfate at $800^{\circ} \mathrm{C}$ or oxide at $1250^{\circ} \mathrm{C}$. The platinum column is then sealed and shipped to the user, who can dissolve and remove the product by passing nitric acid through the column. Process operating conditions and equipment requirements were first defined by tests with stainless steel columns using dysprosium as a stand-in for the transplutonium isotopes. Calcination tests were then conducted to demonstrate the process in platinum columns with terbium, californium-252, curium-242, and curium-244. 


\section{CONTENTS}

\section{$\underline{\text { Page }}$}

Introduction . . . . . . . . . . . . . . . . . 5

Summary. . . . . . . . . . . . . . . . . . . 7

Discussion . . . . . . . . . . . . . . . . . . 9

Previous Studies. . . . . . . . . . . . . . . . 9

Experimental Approach . . . . . . . . . . . . . . 9

Resin Loading and Column Preparation. . . . . . . . . 10

Product Loading . . . . . . . . . . . . . . . . 11

Tests with Stainless Steel Columns . . . . . . . . . 12

Thermal Behavior . . . . . . . . . . . . 15

Product Form . . . . . . . . . . . . . . 23

Off-Gases. . . . . . . . . . . . . . . . . 24

Tests with Platinum Columns . . . . . . . . . . 26

Californium. . . . . . . . . . . . . . 26

Terbium Stand-in . . . . . . . . . . . . 27

Curium . . . . . . . . . . . . . . . . 28

Product Removal and Purity. . . . . . . . . . . . 29

Recovery of Product Losses. . . . . . . . . . . . 31

References . . . . . . . . . . . . . . . . 32 


\section{LIST OF TABLES AND FIGURES}

$\underline{\text { Page }}$

Table

I Resin Calcination in Stainless Steel Columns. . . . . 14

II Thermal Tests in Stainless Steel Columns. . . . . . 22

II Off-Gas Composition from Test 8 . . . . . . . . . 25

IV Resin Calcination in Platinum Columns . . . . . . 26

V Product Purity. . . . . . . . . . . . . 30

\section{Figure}

1 Recovery and Purification of ${ }^{252} \mathrm{Cf}$. . . . . . . . . 5

2 Recovery of ${ }^{252} \mathrm{Cf}$ by Resin Calcination . . . . . . . 7

3 Resin Calcination Equipment. . . . . . . . . . 11

4 Apparatus for Calcination of Resin in Stainless Stee 1 Columns............ . . . . . . 12

5 Differential Thermal Analysis of Resin Used in Stainless Steel Columns................ 15

6 Resin Calcination in $5-\mathrm{cm}^{3}$ Column (Test 1) . . . . 16

7 Resin Calcination in $50-\mathrm{cm}^{3}$ Column (Test 2) . . . . 17

8 Pressure Increase During Calcination . . . . . . 18

9 Effects of Air Flow and Volume on Resin Calcination. . 20

10 Rate of Temperature Increase at Ignition . . . . . . 21

11 Product Form . . . . . . . . . . . . . 23

12 Off-Gas Composition in Test $8\left(\mathrm{SO}_{2}\right.$-Free Basis) . . . . 25

13 Calcination of ${ }^{242} \mathrm{Cm}-{ }^{244} \mathrm{Cm}$ in Resin . . . . . . . . . 29 


\section{INTRODUCTION}

Several grams of ${ }^{252} \mathrm{Cf}$ are being produced at Savannah River for evaluation as neutron sources. The ${ }^{252} \mathrm{Cf}$ is produced by irradiation of targets containing the higher isotopes of plutonium, americium, and curium. In addition to californium, the byproducts berkelium, einsteinium, and fermium may be present in recoverable quantities. A general description of the overall program has been given in previous reports ${ }^{1-3}$ and is shown in Figure 1.

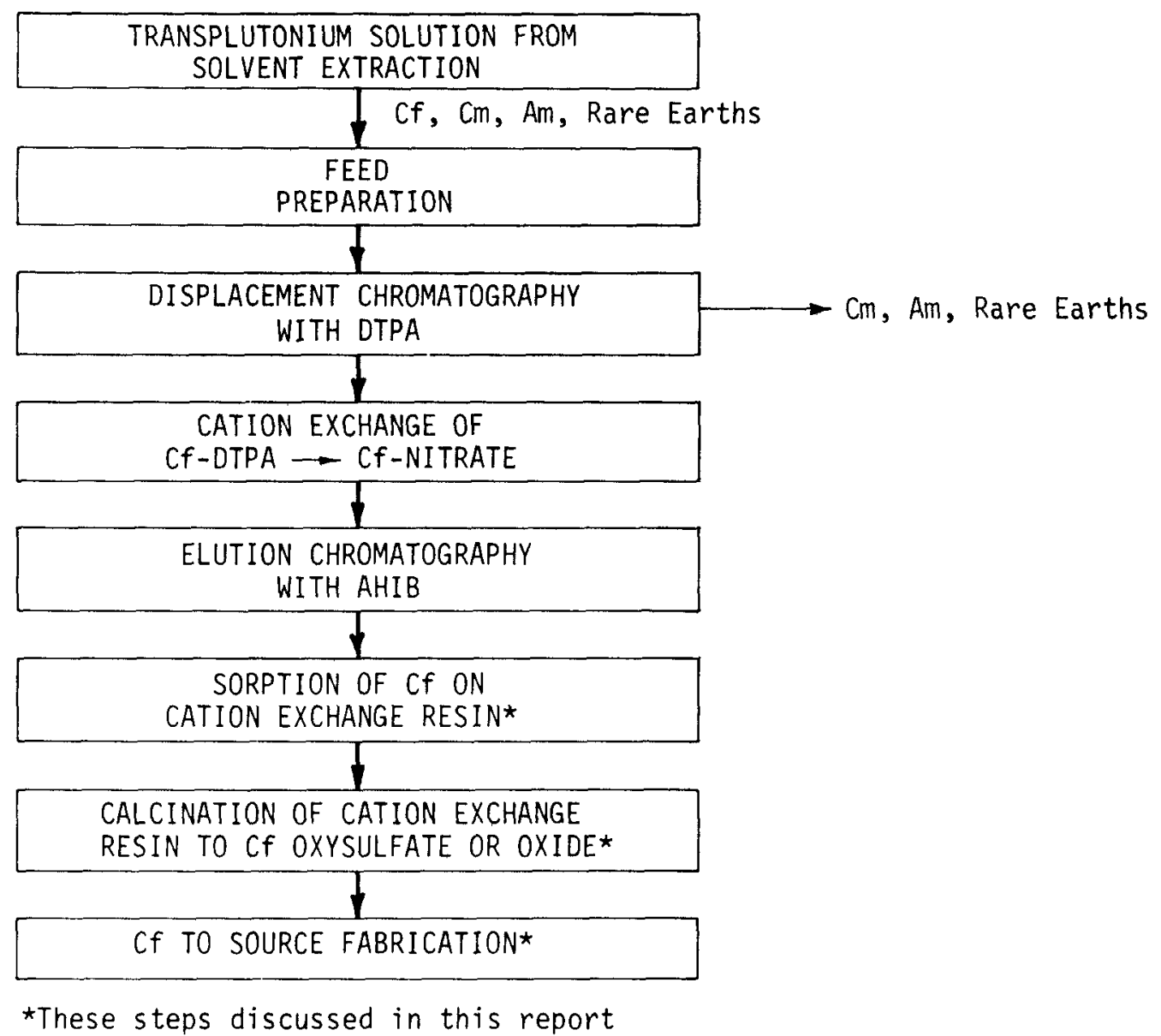

FIGURE 1. Recovery and Purification of ${ }^{252} \mathrm{Cf}$ 
In the separations process planned for use at Savannah River, the irradiated targets are dissolved in nitric acid, and plutonium is separated by a conventional solvent extraction process with dilute tributylphosphate (TBP). This feed is then divided into batches for ion exchange processing. After a feed preparation step, californium, americium, and curium are partially separated from each other and from lanthanide fission products by pressurized displacement development chromatography on cation exchange resin with diethylenetriaminepentaacetic acid (DTPA). The californium is separated from DTPA solution by conventional cation exchange, and californium is eluted from this column with nitric acid. The nitric acid concentration is then reduced, and the solution is fed to a second pressurized cation exchange column where the californium is further purified by elution development chromatography using alphahydroxyisobutyrate (AHIB).

Processing steps were required for use following the elution development chromatography to separate the californium from the large volume of $A H I B$ and to isolate it in a form suitable for shipping and subsequent dissolution in nitric acid. The method chosen was sorption of $2100 \mathrm{mg}$ of ${ }^{252} \mathrm{Cf}$ from the AHIB solution on cation resin contained in a $50-\mathrm{cm}^{3}$ platinum column; the resin is then burned in the column to yield californium oxysulfate or oxide. The column is then sealed and sent to the user who removes the californium from the column with nitric acid.

The work reported here had the following principal objectives:

- Demonstrate conditions for quantitative sorption of californium from AHIB solution on a small volume of cation exchange resin.

- Determine optimum conditions for safe burning of the cation exchange resin to yield a californium product soluble in nitric acid and low in cationic impurities.

- Demonstrate that the californium oxysulfate or oxide produced by calcination can be quantitatively removed from the column.

Although these studies were carried out principally for the purpose of developing a plant-scale process for ${ }^{252} \mathrm{Cf}$ recovery, the equipment and techniques developed are also applicable to the other transplutonium isotopes. The same equipment and techniques will be used to recover byproducts berkelium, einsteinium, and fermium. 


\section{SUMMARY}

A plant-scale resin calcination system was developed to prepare $2100 \mathrm{mg}$ of californium oxysulfate or oxide without directly handling small quantities of liquids or solids. The californium is sorbed on a small volume of cation resin in a platinum column, the resin is burned, and the column is heated to form either oxysulfate at $800^{\circ} \mathrm{C}$ or oxide at $1250^{\circ} \mathrm{C}$. The platinum column is then sealed and shipped to the user, who can dissolve and remove the californium by passing nitric acid through the column. The steps involved in this process are shown in Figure 2.

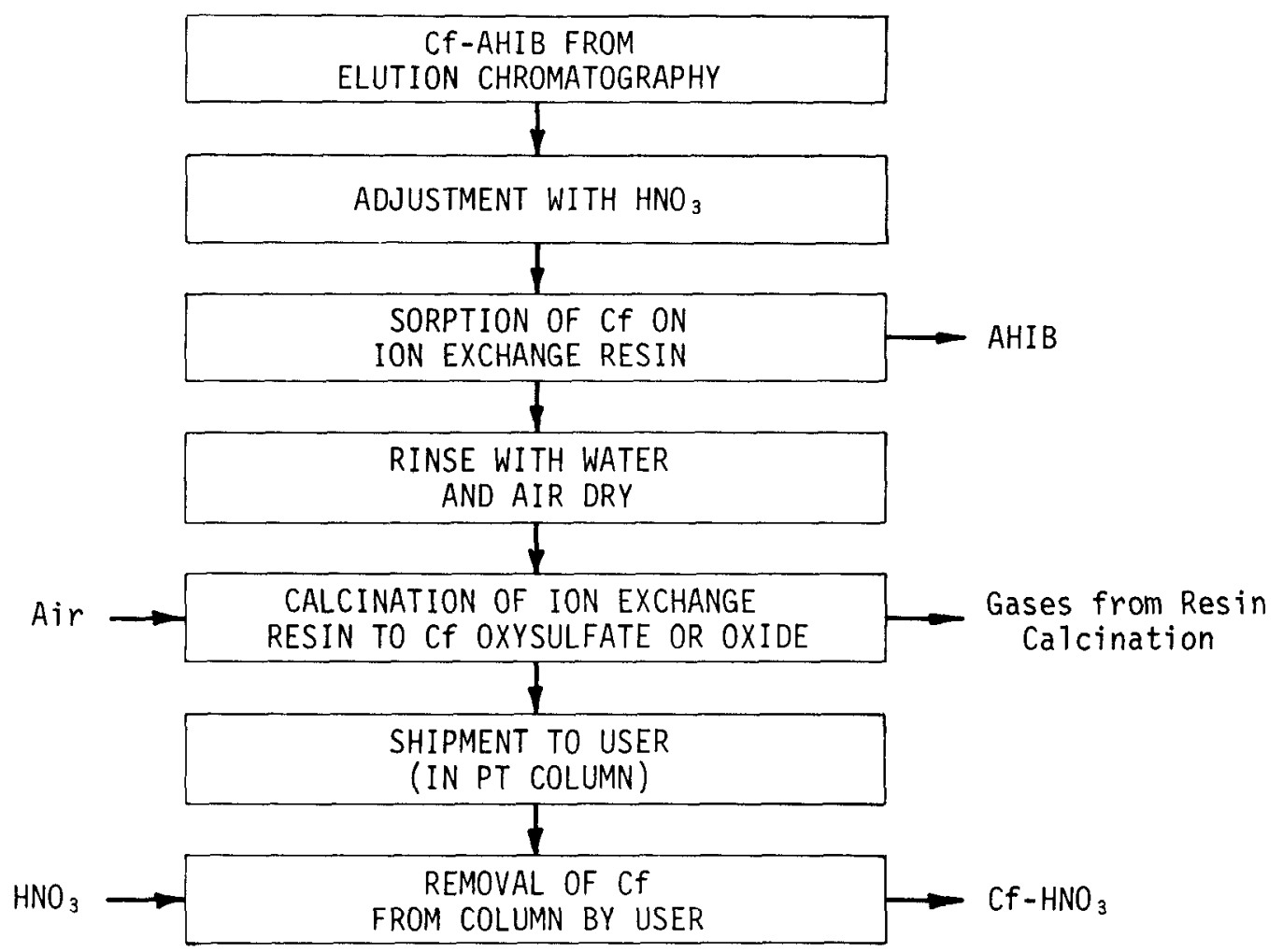

FIGURE 2. Recovery of ${ }^{252} \mathrm{Cf}$ by Resin Calcination 
Process operating conditions and equipment requirements were first defined by tests with stainless steel columns using dysprosium as a stand-in for the transplutonium isotopes. Calcination tests were then conducted to demonstrate the process in platinum columns with terbium, californium-252, curium-242, and curium-244.

Al1 phases of the process were demonstrated, including column loading, resin calcination, and product removal. Techniques were also demonstrated for recovery of product lost from a column due to a leaking or ruptured frit. 


\section{DISCUSSION}

\section{PREVIOUS STUDIES}

The oxides of californium ${ }^{4}$ and berkelium ${ }^{5}$ have been prepared by heating single beads of cation exchange resin at 1200 to $1250^{\circ} \mathrm{C}$. Two-gram samples of "Dowex"* 50W-X8, 50- to 100-mesh resin saturated with neodymium (as a stand-in for $\mathrm{Cf}$ and $\mathrm{Cm}$ ) were calcined by $\mathrm{Hale}^{6}$ in open platinum containers with air and oxygen to yield $\mathrm{Nd}_{2} \mathrm{O}_{2} \mathrm{SO}_{4}$ at $600-1000^{\circ} \mathrm{C}$ and $\mathrm{Nd}_{2} \mathrm{O}_{3}$ at $1200^{\circ} \mathrm{C}$ and above.

Oak Ridge National Laboratory has developed several new encapsulation techniques for fabrication of sources containing up to $5 \mathrm{mg}$ of ${ }^{252} \mathrm{Cf} .{ }^{7,8}$ One of these techniques involves the use of resin calcination. ${ }^{8}$ The primary container consists of a 3/8-inch-OD by 1 -inch-long platinum-plated column filled with ion exchange resin. The ${ }^{252} \mathrm{Cf}$ is loaded onto the resin, and then the resin is calcined at $650^{\circ} \mathrm{C}$ for 3 hours in a low air flow. The capsule is then sealed and welded into a secondary container for shipping.

\section{EXPERIMENTAL APPROACH}

Differential thermal analyses were carried out in flowing air with small samples of resin. These tests were conducted to determine the ignition behavior of small quantities of various resins, including unirradiated resin, resin irradiated in water and then washed, and damp irradiated resin.

Due to the high cost of platinum and the limited availability of ${ }^{252} \mathrm{Cf}$, process development was carried out by first making resin calcination tests using stainless steel equipment with dysprosium as a nonradioactive stand-in for ${ }^{252} \mathrm{Cf}$ at temperatures up to $800^{\circ} \mathrm{C}$. These tests defined the calcination conditions, equipment requirements, process control, yields, and process operating behavior. Microscopic examination of the calcined product gave evidence of the particle size distribution, but stainless steel corrosion products prevented exact determination of product purity. Corrosion of the stainless steel also precluded calcination at temperatures in excess of $800^{\circ} \mathrm{C}$.

A total of twelve calcination tests were made in stainless steel columns. Two of the tests were in $5-\mathrm{cm}^{3}$ columns, and the remainder were in plant-scale $50-\mathrm{cm}^{3}$ columns.

\footnotetext{
ॠRegistered trademark of Dow Chemical Co.
} 
After determining operating conditions and process behavior with the stainless steel columns, calcination tests were conducted in platinum columns that contained ion exchange resin loaded with small ( $<1 \mathrm{mg}$ ) quantities of ${ }^{252} \mathrm{Cf}$ and with plant-scale quantities ( $100 \mathrm{mg}$ ) of ${ }^{244} \mathrm{Cm},{ }^{242} \mathrm{Cm}$, and terbium as stand-ins for ${ }^{252} \mathrm{Cf}$. These tests further confirmed operating conditions and product yield and purity. Five calcination tests were made in the platinum columns. Two of the tests were made with $<1 \mathrm{mg}$ of ${ }^{252} \mathrm{Cf}$ in $5-\mathrm{cm}^{3}$ columns, two tests were made with $\mathrm{Tb}$ and ${ }^{244} \mathrm{Cm}$ as stand-ins for $252 \mathrm{Cf}$ in plant-scale $50-\mathrm{cm}^{3}$ columns, and a final test was made with 2100 $\mathrm{mg}$ of a mixture of ${ }^{242} \mathrm{Cm}$ and ${ }^{24} \mathrm{Cm}$ in a $50-\mathrm{cm}^{3}$ column that simulated both the mass and the nuclear energy ( 2.5 watts) expected for a fu11-scale ${ }^{252} \mathrm{Cf}$ calcination.

Tests in the stainless steel and platinum columns demonstrated all phases of the process, including column loading, resin calcination, and product removal. Tests were also conducted to determine methods of recovering any product that might be lost from the column due to a defective frit which might leak or rupture.

\section{RESIN LOADING AND COLUMN PREPARATION}

In plant-scale processing, $100 \mathrm{mg}$ of ${ }^{252} \mathrm{Cf}$ will be loaded onto $~ 250 \mathrm{ml}$ of "Dowex" $50 \mathrm{~W}-\mathrm{X} 8,50$ to 100-mesh resin from several liters of $0.4 \mathrm{M}$ AHIB solution adjusted to $0.25 \mathrm{M} \mathrm{HNO}_{3}$. The size of the column is fixed mainly by the column loading step. The diameter is $\sim 1$ inch for adequate loading rate, and the length is $\sim 5$ inches to ensure all the product will be retained by the resin. The stainless steel columns used for the cold tests were of the same dimensions as those for the hot test; they differed only in that six thermocouples were attached externally to better define resin burning behavior in the hot test (Figure 3 ).

For two tests, each with $\sim 1 \mathrm{mg}$ of ${ }^{252} \mathrm{Cf}$, platinum columns of $3 / 8$-inch diameter and $\sim 5$-inch length containing $\sim 4.5 \mathrm{ml}$ of "Dowex" $50 W-X 8$ resin were used. Two 3/8-inch-diameter stainless steel columns were also tested. The resin was contained between two $\mathrm{H}$-porosity platinum frits. All interior portions of the columns were platinum or platinum-rhodium to prevent contamination of the product with cationic corrosion products. The columns were designed for at least $100 \mathrm{psig}$ at $600^{\circ} \mathrm{C}$.

Each column was loaded with resin from a water slurry to within $21 / 4$ inch of the top frit to prevent channels or voids in the resin. The resin temperature did not exceed $100^{\circ} \mathrm{C}$ during welding of the second platinum frit to retain the resin. After the resin was sealed in place between the frits, the column was flow tested with water and air. The columns gave a water flow of $50 \mathrm{ml} / \mathrm{min}$ at $<10 \mathrm{psig}$ and an air flow of 1 iiter/minute at $<5$ psig. 

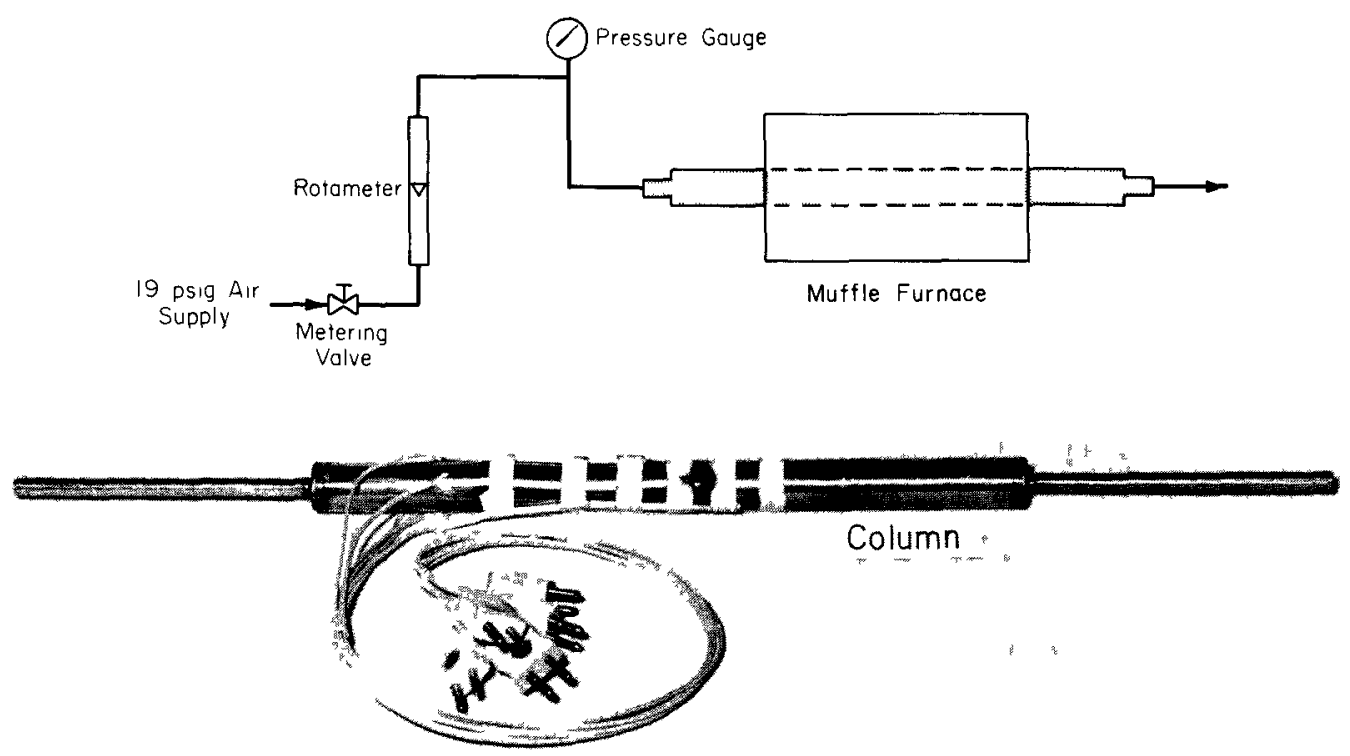

FIGURE 3. Resin Calcination Equipment

\section{PRODUCT LOADING}

The Cf-AHIB fraction from elution development chromatography is adjusted to $0.25 \mathrm{M} \mathrm{HNO}_{3}$ to decrease the ligand concentration, so that californium is effectively sorbed by the cation resin. At lower concentrations, sorption is less effective because of complexing of the metal ion by AHIB, and at higher concentrations of acid, sorption is less effective because of competition for the resin sites by hydrogen ion. In all tests, either the feed was produced by elution development chromatography with AHIB, or a synthetic feed was prepared using $0.4 \mathrm{M}$ AHIB at $\mathrm{pH} 3.4$.

The column was loaded by: 1) direct pumping of the adjusted AHIB solution to the column, or 2) displacement of the AHIB solution from the feed tank with three tank volumes of dilute nitric acid; the latter method is planned for plant operation. The flow to the column was 50 to $100 \mathrm{ml} / \mathrm{min}$, and $10 \mathrm{ss}$ to the absorption effluent was always $<0.1 \%$. Analyses were obtained on "flowing stream" samples of the effluent and also on a sample of the total effluent. In the plant system, the effluent will be passed through a monitoring loop equipped with high- and low-range $\mathrm{BF}_{3}$ detectors to detect californium breakthrough.

After sorption, the loaded resin was washed with 0.5 liter of water to remove most of the nitric acid and AHIB. Then the resin was air-dried for $\sim 30$ minutes by applying vacuum at the column outlet. 


\section{TESTS WITH STAINLESS STEEL COLUMNS}

Resin calcination tests were made in stainless steel columns to define calcination conditions, equipment requirements, process control, yields, and process operating characteristics. Microscopic examination of the calcined product defined particle size distribution, but corrosion products of stainless steel prevented determination of product purity.

Resin columns were loaded with $00.4 \mathrm{mmol}$ of dysprosium (equivalent to $100 \mathrm{mg}$ of ${ }^{252} \mathrm{Cf}$ ) from an $\mathrm{AHIB}$ solution as described previously. Two tests were made without dysprosium loading; however, only $\sim 1 \%$ of the resin exchange sites are required to contain all of the dysprosium, so that in all tests the resin was essentially all in the $\mathrm{H}^{+}$form. Each column was washed and air dried, and the resin calcined in flowing air by heating the column in the apparatus shown in Figure 4. The off-gas equipment and additional inlet tubing were added for the later tests.

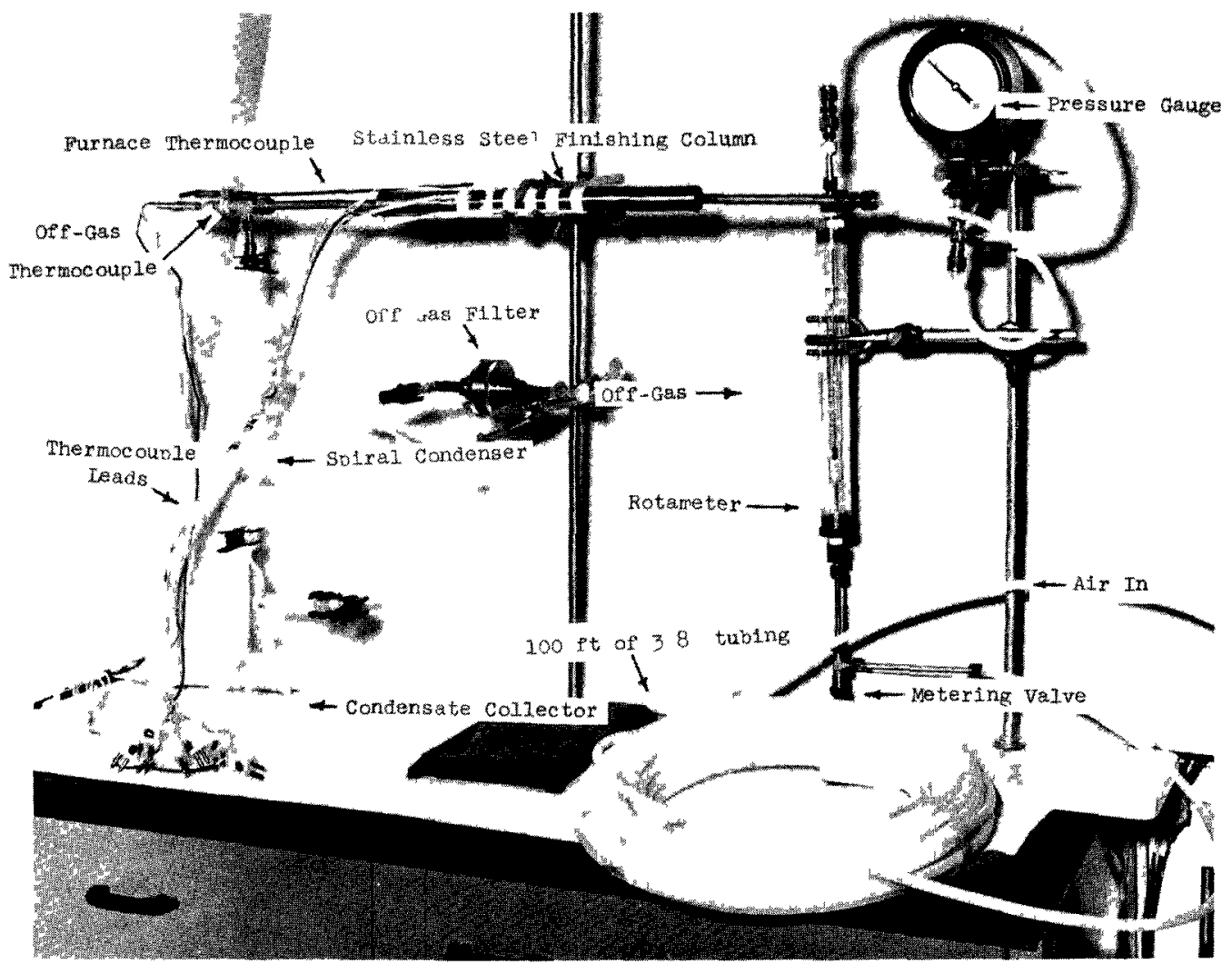

FIGURE 4. Apparatus for Calcination of Resin in Stainless Steel Columns 
Each column was heated from $\sim 25$ to $400^{\circ} \mathrm{C}$ in 1 hour, from 400 to $800^{\circ} \mathrm{C}$ in 3 hours, and then cooled and opened to examine the product, determine that all resin had burned, and examine the general condition of the column. In several tests the calcined product was leached out with nitric acid before the column was opened. The tests are summarized in Table I.

Resin calcination tests in the stainless steel columns established the following:

- The resin was completely burned in 3 hours or less at an air flow rate of 1 liter/minute through the $50-\mathrm{cm}^{3}$ columns.

- The ignition and burning of the resin did not result in unacceptably high temperatures at the air flow rates investigated (up to 2.25 liters/minute).

- Most of the product was in the form of spherical particles of approximately the same size as the original resin beads. There was no significant loss of product fines through the G-porosity outlet frit.

- The product formed at $800^{\circ} \mathrm{C}$ was mainly oxysulfate and was easily dissolved in dilute nitric acid.

- Elimination of channels in the resin by filling and compacting resin to within $\approx 1 / 4$ inch of the top frit ensured efficient and predictable resin burning rates.

- Pressure and temperature surges and a decrease in air flow at ignition provided convenient means of determining that ignition had occurred.

- The principal gaseous combustion products were $\mathrm{SO}_{2}$ and $\mathrm{CO}_{2}\left(<1 \% \mathrm{H}_{2}, \mathrm{CH}_{4}\right.$, or $\left.\mathrm{CO}\right)$.

- Al1 portions of the system must be heated to $>400^{\circ} \mathrm{C}$ to prevent condensation of organic pyrolysis products.

- The off-gas should be passed through a condenser and one or more filters to remove moisture and organic tars. Filters should be changed periodically due to the accumulation of tar. 
TABLE I

Resin Calcination In Stainless Steel Columns

\begin{tabular}{|c|c|c|c|c|}
\hline Test & $\begin{array}{c}\text { Column } \\
\text { Volume } \\
\mathrm{cm}^{3} \\
\end{array}$ & $\begin{array}{l}\text { Air } \\
\text { Velocity, } \\
\mathrm{cm} / \mathrm{sec} \\
\end{array}$ & Off-Gas System & Notes \\
\hline 1 & 5 & 16.7 & - & No stand-in. \\
\hline 2 & 50 & $4.9^{u}$ & - & No stand-in. \\
\hline 3 & 50 & 4.9 & Filter & $\begin{array}{l}\text { Oxysulfate product. } \\
\text { Analysis for Dy in all } \\
\text { downstream portions of } \\
\text { system. }\end{array}$ \\
\hline 4 & 5 & 12.5 & Filter & $\begin{array}{l}\text { Channel; } \sim 1 / 2 \text { burned; } \\
\text { no ignition. }\end{array}$ \\
\hline 5 & 50 & 4.9 & Filter, Condenser & $\begin{array}{l}\text { Microscopic exam of } \\
\text { product; gas samples. }\end{array}$ \\
\hline 6 & 50 & 4.9 & $\begin{array}{l}\mathrm{Filter} \text {, Condenser } \\
\mathrm{H}_{2} \mathrm{SO}_{4} \text { Absorber, } \\
\text { Drierite Column }\end{array}$ & $\begin{array}{l}\text { Dysprosium leached from } \\
\text { column; gas samples. }\end{array}$ \\
\hline 7 & 50 & 4.9 & $\begin{array}{l}\text { Filter, Coiled } \\
\text { Condenser }\end{array}$ & $\begin{array}{l}\text { Dysprosium leached from } \\
\text { column; gas samples. }\end{array}$ \\
\hline 8 & 50 & 4.9 & $\begin{array}{l}\text { Filter, Coiled } \\
\text { Condenser }\end{array}$ & $\begin{array}{l}\text { Dysprosium leached from } \\
\text { column; gas samples. }\end{array}$ \\
\hline 9 & 50 & 7.3 & $\begin{array}{l}\text { Filter, Coiled } \\
\text { Condenser }\end{array}$ & $\begin{array}{l}\text { Microscopic exam of } \\
\text { product; gas samples. }\end{array}$ \\
\hline 10 & 50 & 11.0 & $\begin{array}{l}\text { Filter, Coiled } \\
\text { Condenser }\end{array}$ & $\begin{array}{l}\text { Microscopic exam of } \\
\text { product; } 675^{\circ} \mathrm{C} \text { at } \\
\text { v } 0 \text { min after } 450^{\circ} \mathrm{C} \\
\text { ignition. }\end{array}$ \\
\hline 11 & 50 & 4.9 & $\begin{array}{l}\text { Filter, Coiled } \\
\text { Condenser }\end{array}$ & $\begin{array}{l}106 \mathrm{ft} \text { of } 3 / 8 \mathrm{in} \text {. tubing } \\
\text { added to inlet; microscopic } \\
\text { exam of product. }\end{array}$ \\
\hline 12 & 50 & 11.0 & $\begin{array}{l}\text { Filter, Coiled } \\
\text { Condenser }\end{array}$ & $\begin{array}{l}106 \mathrm{ft} \text { of } 3 / 8 \mathrm{in.} \mathrm{tubina} \\
\text { added to inlet; system } \\
\text { shut down after ignition } \\
\text { and restarted at lower } \\
\text { air flow rate; } \\
\text { microscopic exam of product }\end{array}$ \\
\hline
\end{tabular}

a. Corresponds to one liter per minute flow in the $50-\mathrm{cm}^{3}$ columns. 


\section{Thermal Behavior}

Thermocouples located on the column, in the off-gas stream and in the furnace cavity gave detailed information on the thermal behavior of the system during calcination. Before the calcinations, differential thermal analyses were conducted with a few milligrams of resin in flowing air to ensure that there would be no unusual exotherms. These tests were carried out on several samples cf resin including unirradiated resin, irradiated resin, and irradiated-washed resin. Resin ignition temperature varied from 290 to $425^{\circ} \mathrm{C}$; the variation was basically a function of the particular batch of resin that was used for the test. No significant correlation was found between irradiation of the resin and ignition temperature. Tests with small samples of the resin used in the stainless steel columns established that this resin should ignite at $2450^{\circ} \mathrm{C}$ and that the ignition would be preceded by an endothermic pyrolysis reaction (Figure 5). Ignition always occurred between approximately 400 and $470^{\circ} \mathrm{C}$ in the stainless steel column tests with this resin. In most tests, a large quantity of organic mist and fog was produced by the endothermic pyrolysis (or decomposition reaction) before ignition ( 300 to $400^{\circ} \mathrm{C}$ ).

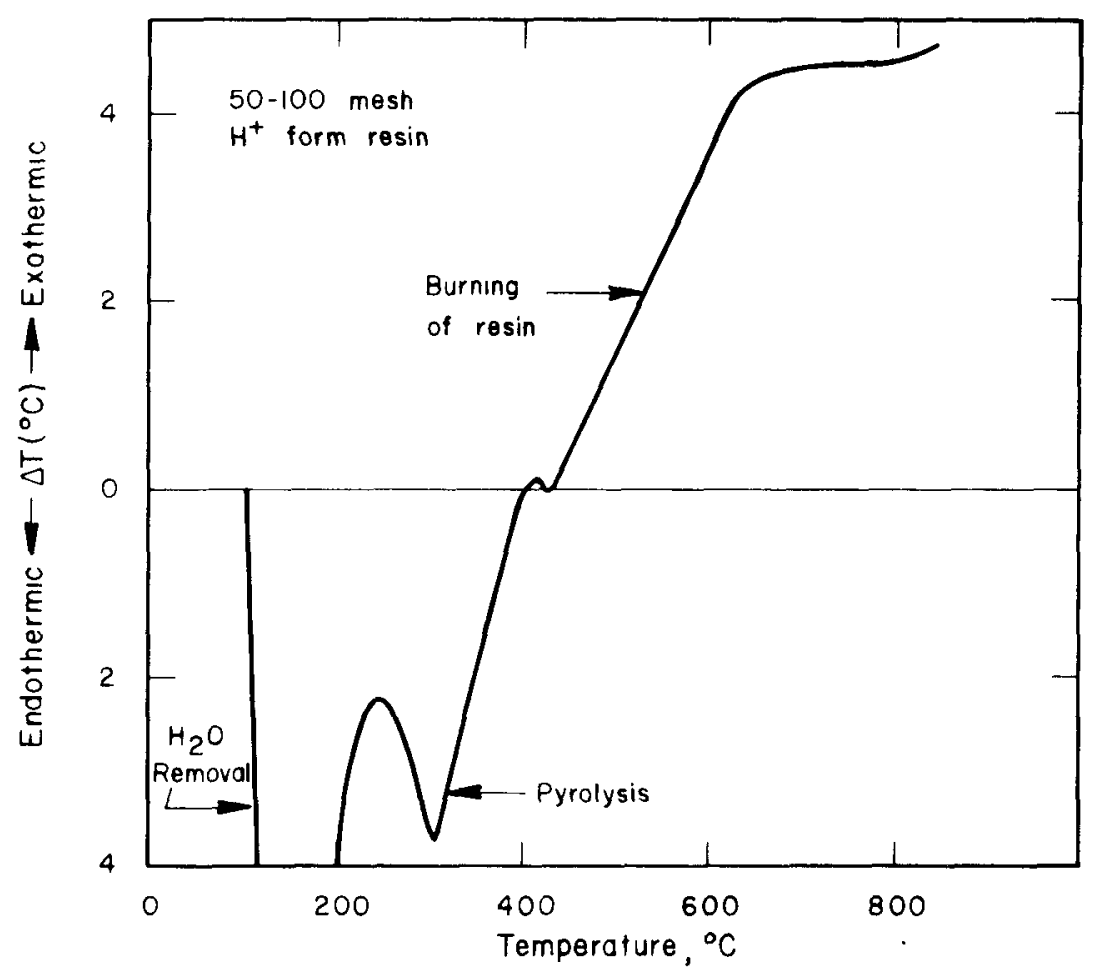

FIGURE 5. Differential Thermal Analysis of Resin Used in Stainless Steel Columns 
The temperature profiles for all tests (except Test 4) were essentially the same. The profiles for Tests 1 and 2 are shown in Figures 6 and 7 as typical examples.

Due to heat losses from the ends of the furnace, initially the center of the column was always at the highest temperature, and ignition occurred in this area. The column inlet was always at a lower temperature than the outlet due to the cooling effect of the inlet air. The heat evolved at ignition increased the temperature of the system rapidly until a new "steady-state" condition was reached at a much higher column temperature. The rate of heat removal from the column (primarily radiant heat transfer) once again equaled the rate of heat generation at the elevated temperature. This transient period lasted approximately 5 to 10 minutes, and the column temperature usually leveled off 100 to $200^{\circ} \mathrm{C}$ higher than before ignition.

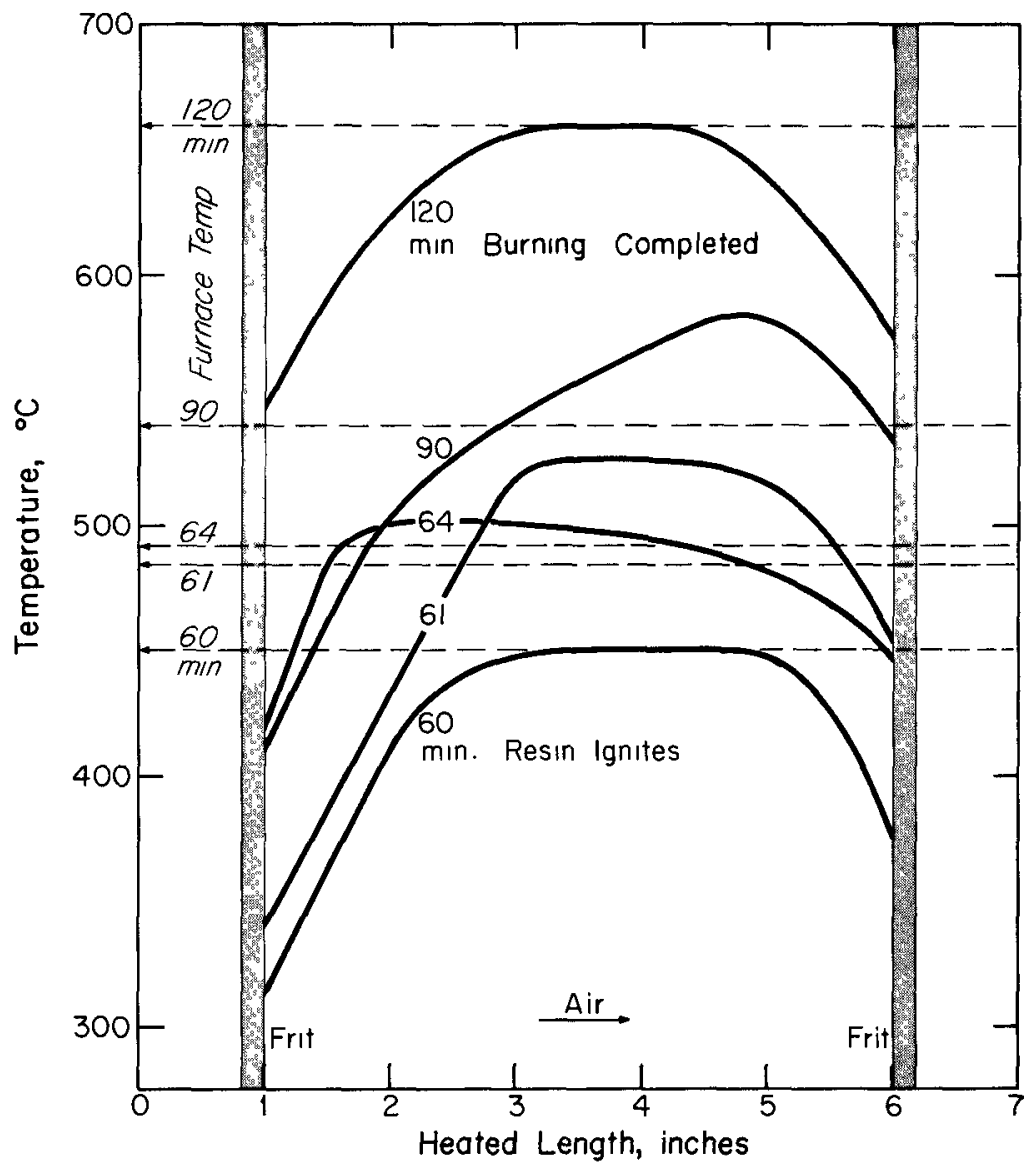

FIGURE 6. Resin Calcination in $5-\mathrm{cm}^{3}$ Column (Test 1) 


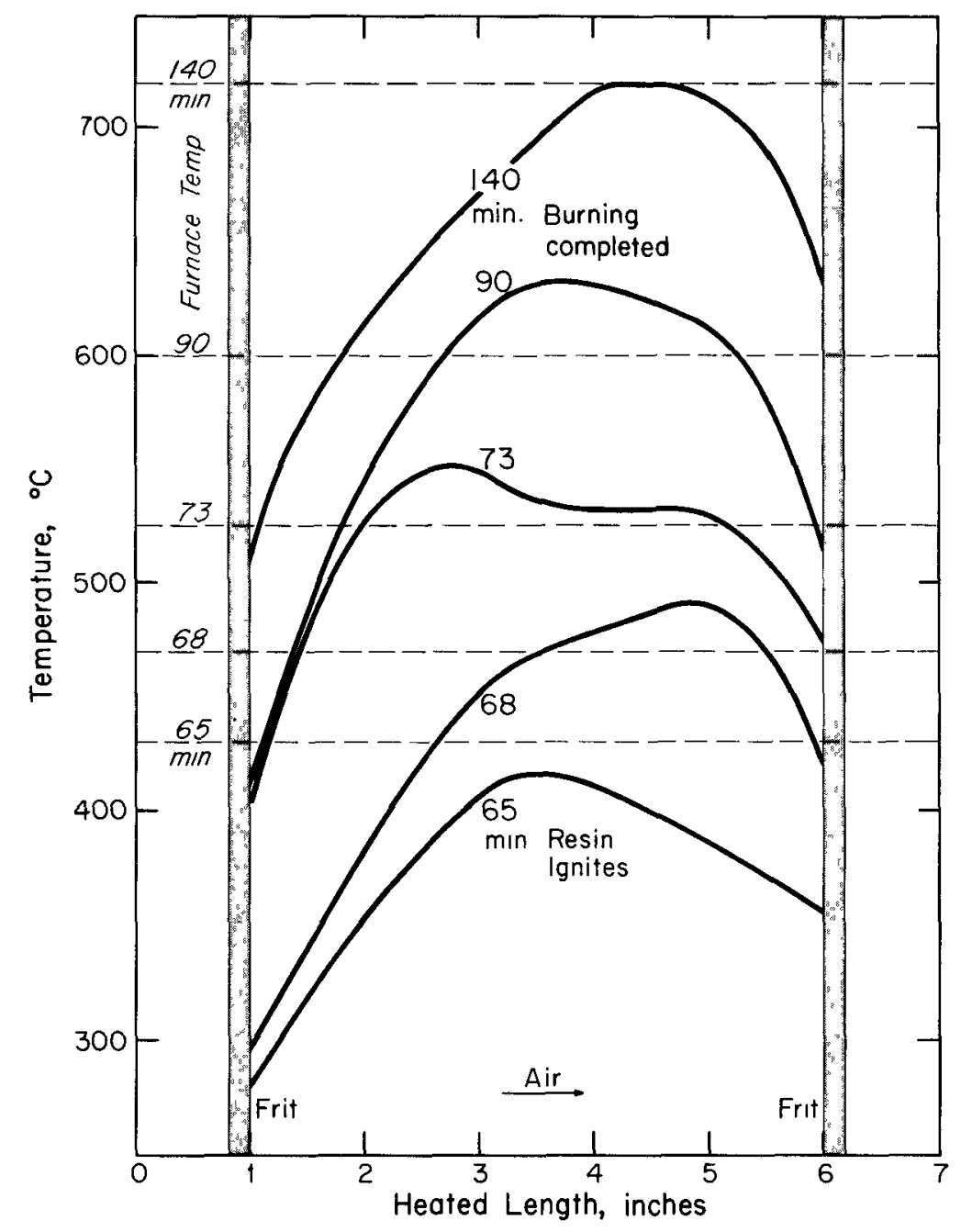

FIGURE 7. Resin Calcination in $50-\mathrm{cm}^{3}$ Column (Test 2) 
Increased system temperature can lead to increased system pressure, especially if the volume of tubing on the system inlet is small. The abrupt increase in pressure at ignition is shown in Figure 8 for Test 2. The air flow rate decreased at ignition. In all tests, the pressure drop necessary to maintain air flow across the column increased with temperature.

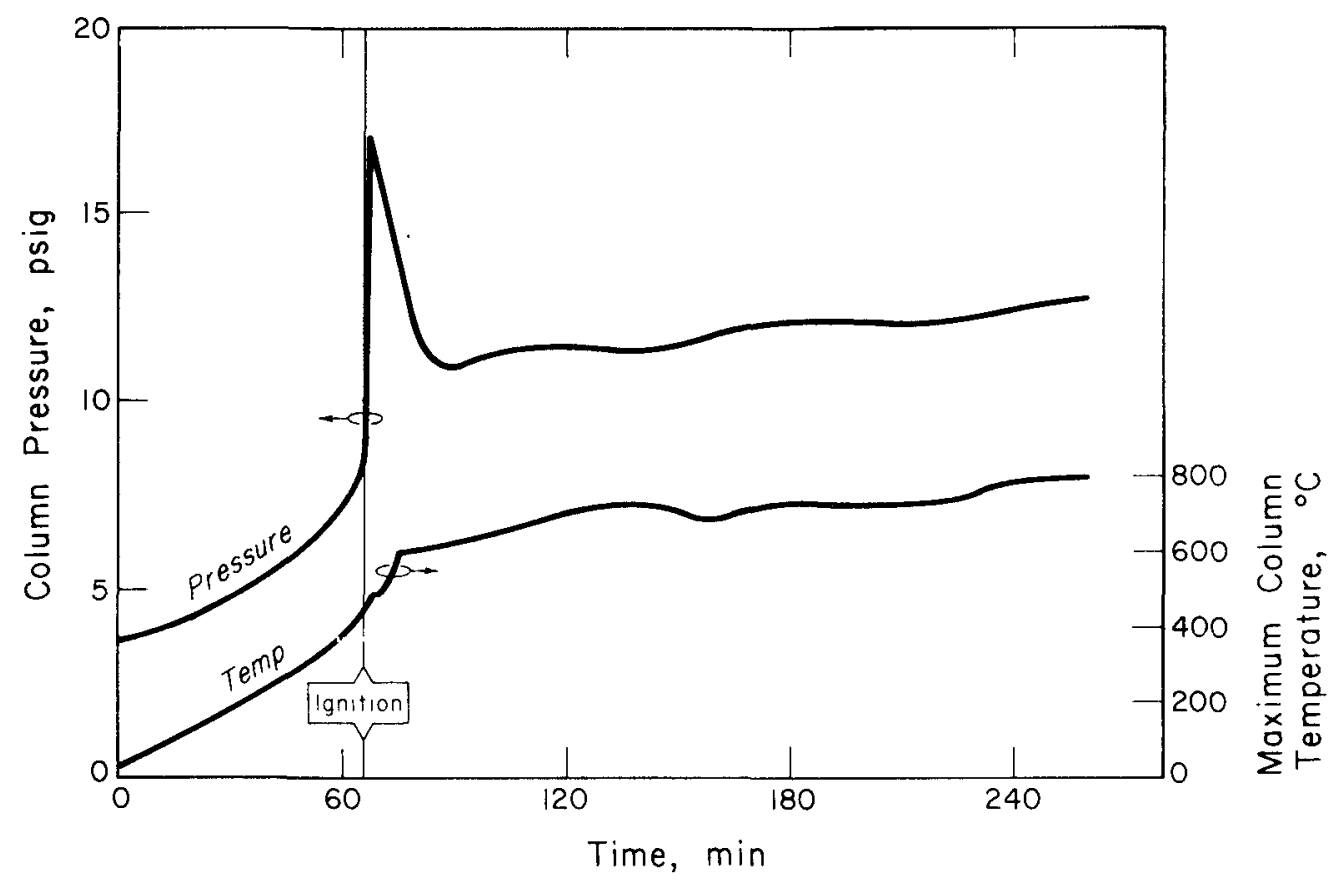

FIGURE 8. Pressure Increase During Calcination

The ignition process is self-regulating. When the system pressure approaches the upstream pressure on the metering valve, air flow decreases due to the decrease in the pressure driving force across the valve. The decrease in the air flow rate immediately decreases the rate of oxidation in the system, and the system pressure never exceeds the upstream pressure.

Oxygen was rapidly depleted in the region of ignition, and as the inlet section was heated to the ignition temperature, the reaction moved toward the column inlet. As oxidation in the inlet section approached completion, the reaction moved back downstream. After all of the resin had been burned, the column temperature became less than or equal to the outside furnace temperature. These various stages are well illustrated in the temperature profiles for Tests 1 and 2 (Figures 6 and 7). 
Test 4 was the only exception to the general ignition behavior. For this test, no ignition was observed and column temperatures never exceeded furnace temperatures. Thermocouples located on the column outlet also gave significantly lower temperatures than those on the column inlet. At the end of the normal 3-hour calcination period, the column was opened for examination; only $\sim 1 / 2$ of the resin had burned. This behavior is attributed to the formation of a channel, due to insufficient packing of the resin in the column. Most of the air bypassed through the channel, and combustion took place only at the interface between the channel and the resin, rather than throughout the resin as in the case of normal plug flow behavior. The cooling of the outlet thermocouple indicates that it was located adjacent to the channel (the thermocouples were located in different positions radially around the column). After this test, all columns were compacted completely to within $1 / 4$ inch of the upper frit, and all flows were in the same direction to maintain a well-packed bed. Normal ignition behavior and complete resin calcination within 3 hours of ignition were observed for all other tests.

Approximately $100 \mathrm{ft}$ of $3 / 8$-inch-OD tubing was added to the column inlet to measure temperature and pressure surges under conditions more closely simulating plant conditions. These tests were run at air flow rates of 1 and 2.25 liters/minute, respectively. Results of these tests and previous tests with $26 \mathrm{ft}$ of tubing on the column inlet are compared in Figure 9. Comparisons of Curve A with $C$ and Curve $B$ with $D$ show that the additional tubing on the column inlet decreases, but does not completely eliminate, the pressure pulse at ignition by acting as a damping reservoir. Comparisons of Curve $A$ with $B$ and Curve $C$ with $D$ also show that the column overtemperature relative to the furnace is proportional to the air flow and is not affected by the length of inlet tubing. The rate of temperature increase at ignition (an index of the oxidation rate) was also greater at higher air flow rates (Figure 10).

In Test 12, as soon as the column temperature leveled out after ignition, the system was shut down by turning off both heat and air flow and cooling to room temperature. The system was then restarted at an air flow of 1 liter/minute and run in the normal manner. The resin reignited; however, the temperature surge was smaller than that obtained in the initial ignition. The second ignition occurred at $\sim 300^{\circ} \mathrm{C}$ (vs. $450^{\circ} \mathrm{C}$ for the first ignition), and the maximum column temperature exceeded the furnace temperature at $2400^{\circ} \mathrm{C}$. Three hours after the second ignition the system was again shut down and the column opened for examination. Approximately $99 \%$ of the resin had been burned, demonstrating the calcination can be interrupted and restarted without problems. 

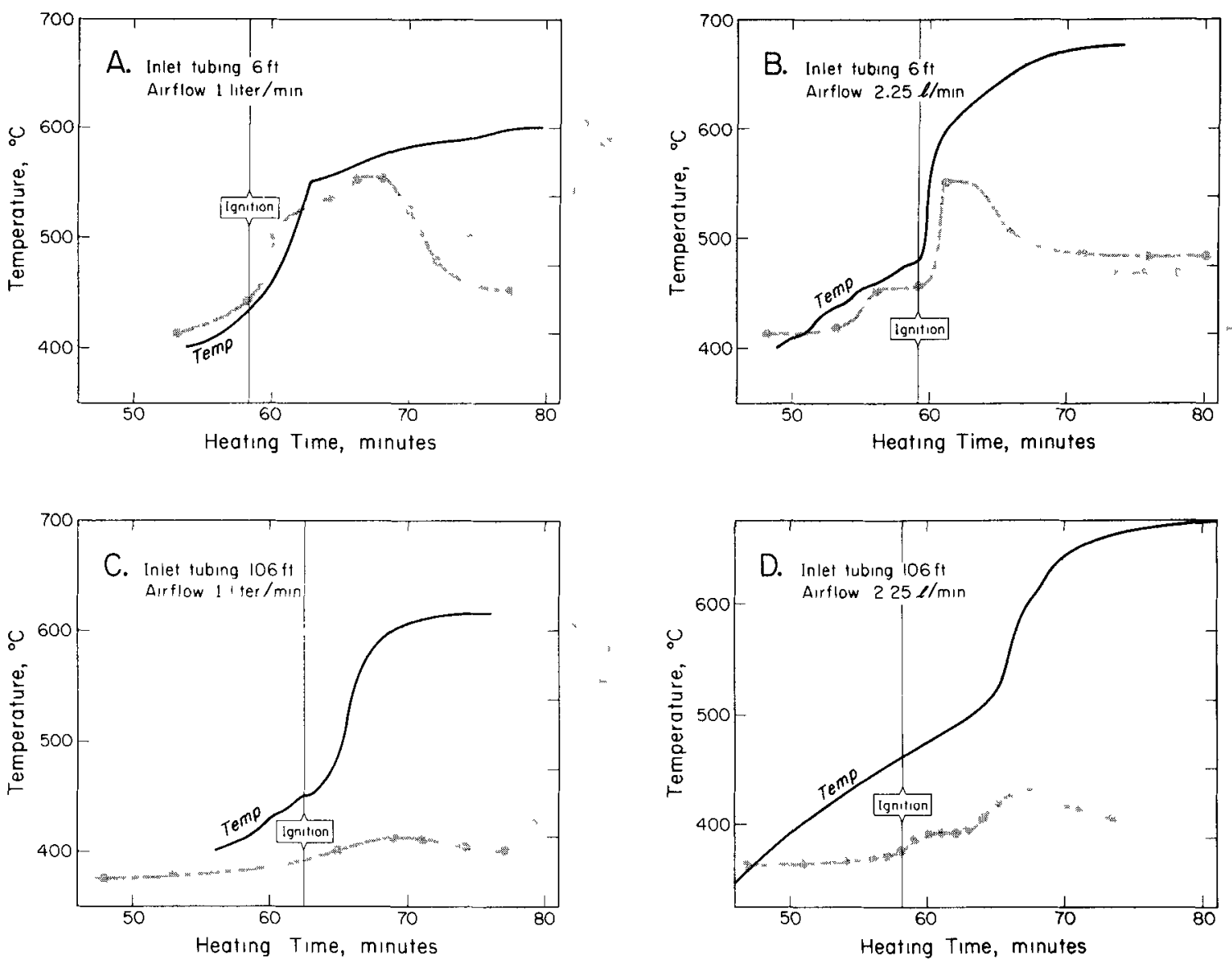

FIGURE 9. Effects of Air Flow and Volume on Resin Calcination 


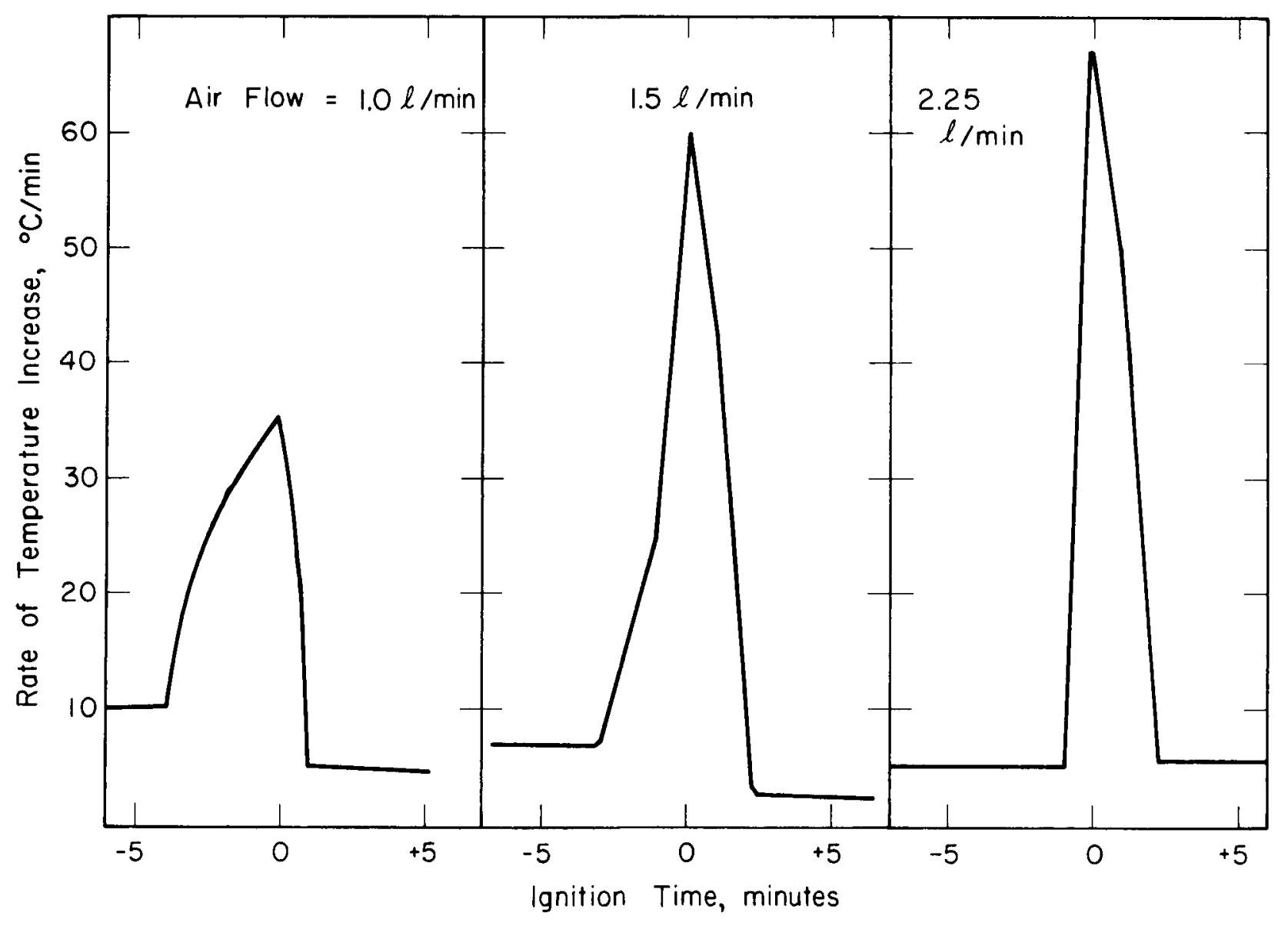

FIGURE 10. Rate of Temperature Increase at Ignition 
A summary of the effect of air flow rate on thermal behavior is given in Table II. At the higher air velocities, the maximum column temperatures at ignition are somewhat higher, and the column temperature increase due to ignition is greater (except in the smaller $5-\mathrm{cm}^{3}$ column used in Test 1). The burning period decreased as the air flow rate was increased.

\section{TABLE II}

Thermal Tests in Stainless Steel Columns

\begin{tabular}{|c|c|c|c|c|}
\hline Test & $\begin{array}{l}\text { Air } \\
\text { Velocity, } \\
\text { cm/sec } \\
\end{array}$ & $\begin{array}{l}\text { Max. Column Temp. } \\
\text { at Ignition, }{ }^{\circ} \mathrm{C} \\
\end{array}$ & $\begin{array}{l}\text { Column Temp. } \\
\text { Increase due to } \\
\text { Ignition, } a{ }^{\circ} \mathrm{C} \\
\end{array}$ & $\begin{array}{l}\text { Burning } \\
\text { Period, } b \\
\text { minutes }\end{array}$ \\
\hline 2 & 4.9 & 410 & 150 & 75 \\
\hline 3 & 4.9 & 430 & 130 & 67 \\
\hline 5 & 4.9 & 460 & 70 & 106 \\
\hline 6 & 4.9 & 405 & 150 & 136 \\
\hline 7 & 4.9 & 440 & 160 & 96 \\
\hline 8 & 4.9 & 435 & 120 & 106 \\
\hline 11 & 4.9 & 445 & 150 & 122 \\
\hline $2-11$ & Avg 4.9 & 432 & 133 & 101 \\
\hline 9 & 7.3 & 440 & 170 & 96 \\
\hline 10 & 11.0 & 470 & 150 & 83 \\
\hline 12 & 11.0 & 450 & 200 & $c$ \\
\hline $1^{d}$ & 16.7 & 460 & 70 & 60 \\
\hline
\end{tabular}

a. Difference between the maximum column temperature at ignition and after the temperature has leveled out (5-10 minutes after ignition).

b. Difference between ignition and point at which the maximum column temperature is no longer greater than the furnace temperature.

c. Test 12 was interrupted after ignition.

d. Test I was in a $5-\mathrm{cm}^{3}$ column. The other tests in this table were in $50-\mathrm{cm}^{3}$ columns. 


\section{Product Form}

The presence of stainless steel corrosion products prevented accurate determination of product purity in these tests; however, the particle size and form of the product were determined, and product losses were estimated. In all tests, the columns were fut open, and the product was weighed and examined to verify that all of the resin had burned.

The product from Test 3 was determined to be oxysulfate from its infrared absorption spectrum. Neutron activation analysis indicated that $<0.01 \%$ of the feed dysprosium was in all downstream portions of the system.

Microscopic examination of the product from these tests indicated that most particles were approximately the same size and shape as the original resin beads, but some spalled at the edges (Figure 11). Almost all of the product was 10 to $100 \mathrm{\mu m}$ in diameter. The product was easily dissolved in dilute nitric acid.

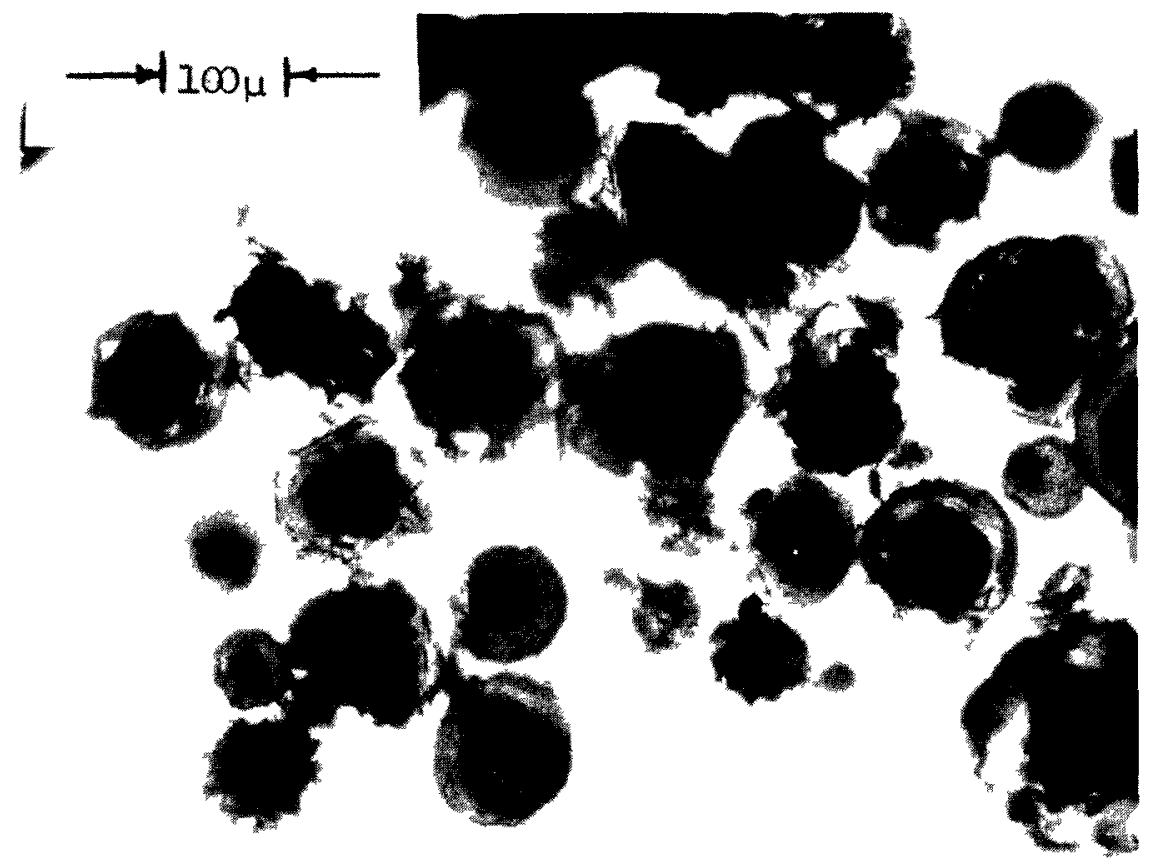

FIGURE 11. Product Form 


\section{Off-Gases}

During calcination all of the resin material is evolved as vapors or gases (except for a small amount of sulfur which combines with the metal to form oxysulfate). Moisture is evolved from the system first at $\sim 100^{\circ} \mathrm{C}$. This water is condensed and collected. At 300 to $400^{\circ} \mathrm{C}$, organic vapors are evolved from the endothermic pyrolysis reaction. These organic vapors condense on surfaces which are below $\sim 400^{\circ} \mathrm{C}$. Therefore all portions of the column that will be subsequently contacted with nitric acid in the product removal step must be maintained above $400^{\circ} \mathrm{C}$ during calcination so no organic material will deposit. A portion of these organic vapors form a fine spray or mist that is difficult to collect. An $\mathrm{H}_{2} \mathrm{SO}_{4}$ absorber followed by a "Drierite" column was added to the off-gas system for removal of this mist in Test 6; however, the small removal of mist obtained in this equipment did not justify its inclusion in subsequent tests. Downstream filters must be changed periodically because they collect these organic materials.

The principal products of combustion were $\mathrm{SO}_{2}, \mathrm{CO}_{2}$, and $\mathrm{H}_{2} \mathrm{O}$. Off-gas samples were taken in Tests 7 and 8 and analyzed for noncondensible gases on an $\mathrm{SO}_{2}$-free basis. At ignition, the $\mathrm{O}_{2}$ concentration decreases and the $\mathrm{CO}_{2}$ concentration increases (Figure 12). A gas sample was taken immediately after ignition in Test 8. At this point, the $\mathrm{O}_{2}$ concentration of the off-gas stream was almost negligible. The concentrations of potentially flammable $\mathrm{H}_{2}, \mathrm{CH}_{4}$, and $\mathrm{CO}$ in the off-gases were less than $1 \%$ in all of the samples (Table III).

Approximately 10 to $20 \mathrm{~cm}^{3}$ of condensate (mainly $\mathrm{H}_{2} \mathrm{O}$ ) were collected during each test. Most of the water, which was in the system initially or was produced by combustion, was collected in the condensate collection vessel. The downstream filters collected much of the organic tars. The remainder of the material evolving from the column passed out of the system in the air stream.

In the plant installation, the downstream submicron filter would prevent loss of californium product in abnormal circumstances, such as fines passing through the downstream column frit or in the case of accidental rupture of the downstream column frit. The probability of significant quantities of product escaping the column by either of these mechanisms is very low.

\footnotetext{
${ }^{\text {Registered }}$ trademark of W. A. Hammond Drierite Company, Xenia, Ohio.
} 
TABLE III

Off-Gas Composition from Test 8

\begin{tabular}{|c|c|c|c|c|c|c|c|}
\hline \multirow{2}{*}{$\begin{array}{c}\text { Time, } \\
\text { minutes }\end{array}$} & \multirow{2}{*}{$\begin{array}{c}\text { Column } \\
\begin{array}{c}\text { Temperature, } \\
{ }^{\circ} \mathrm{C}\end{array} \\
\end{array}$} & \multicolumn{2}{|c|}{ Off-Gas } & \multicolumn{4}{|c|}{ Composition, mol \% } \\
\hline & & $\mathrm{O}_{2}$ & $\mathrm{CO}_{2}$ & $\underline{\mathrm{CO}}$ & $\mathrm{H}_{2}$ & $\mathrm{CH}_{4}$ & $\overline{\mathrm{N}}$ \\
\hline 60 & 425 & 19.4 & 0.4 & $<1$ & 0.1 & 0.1 & 79 \\
\hline 67 & 550 & 1.5 & 12.1 & $<1$ & 0.69 & 0.96 & 83.6 \\
\hline 84 & 625 & 8.2 & 11.0 & $<1$ & 0.08 & 0.015 & 79.8 \\
\hline 110 & 650 & 11.7 & 8.0 & $<1$ & 0.03 & 0.008 & 79.3 \\
\hline 128 & 650 & 14.9 & 5.2 & $<1$ & 0.04 & 0.009 & 78.8 \\
\hline 150 & 650 & 16.7 & 3.0 & $<1$ & 0.018 & 0.007 & 79.0 \\
\hline 178 & 625 & 20.4 & 0.2 & $<1$ & 0.017 & 0.006 & 78.4 \\
\hline 213 & 660 & 20.5 & 0.07 & $<1$ & 0.017 & 0.007 & 78.5 \\
\hline
\end{tabular}

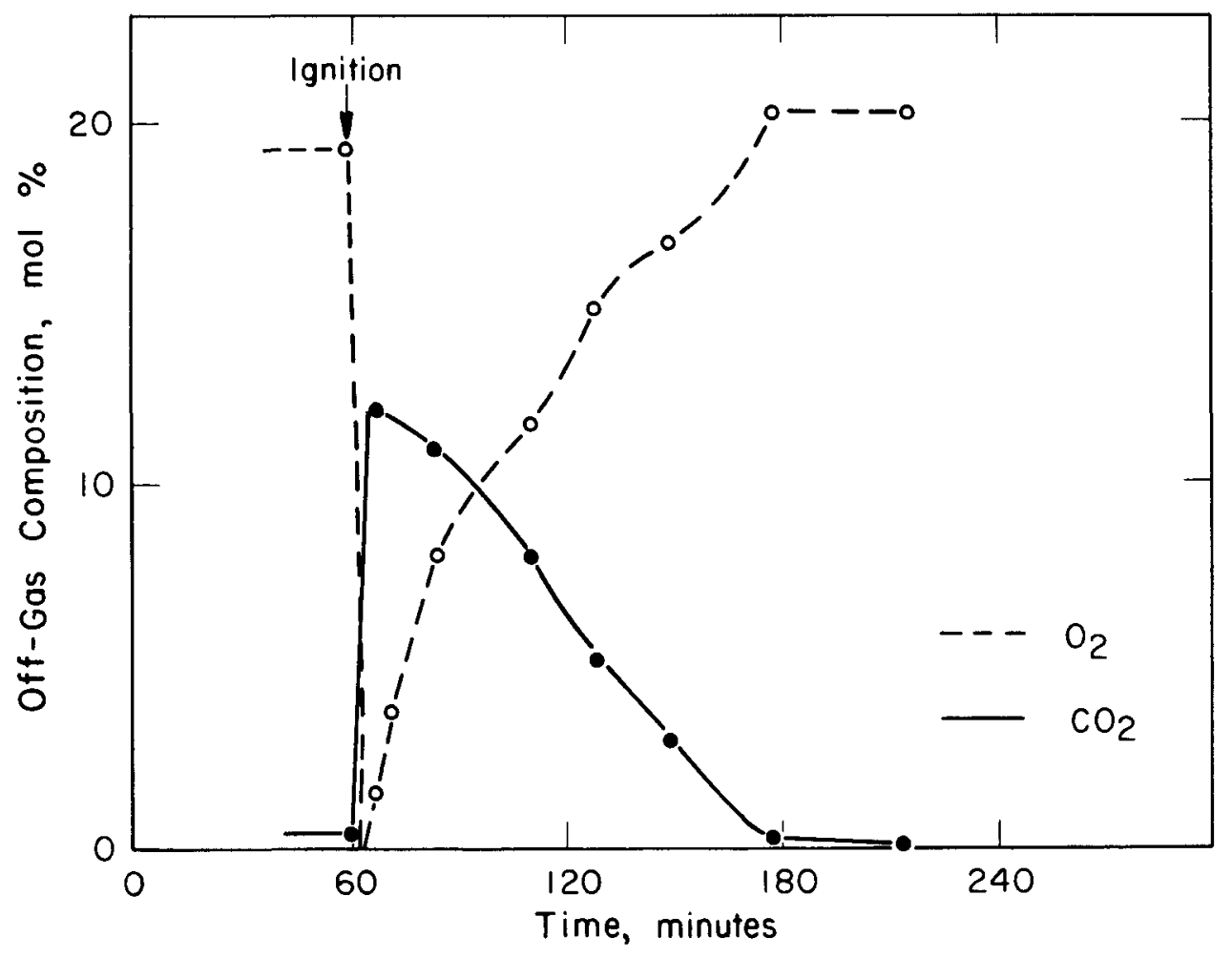

FIGURE 12. Off-Gas Composition in Test $8\left(\mathrm{SO}_{2}\right.$-Free Basis) 


\section{TESTS WITH PLATINUM COLUMNS}

Several tests were made with platinum columns to establish that the cationic impurities in the calcined product were no greater than in the feed to the ion exchange sorption. These tests further confirmed the operating conditions and resin ignition properties, which had been defined initially in stainless steel columns. These tests also showed that there was no significant change in pressure drop across the H-porosity platinum frits after heating to $1250^{\circ} \mathrm{C}$ for as long as 16 hours. These tests are summarized in Table IV.

TABLE IV

Resin Calcination in Platinum Columns

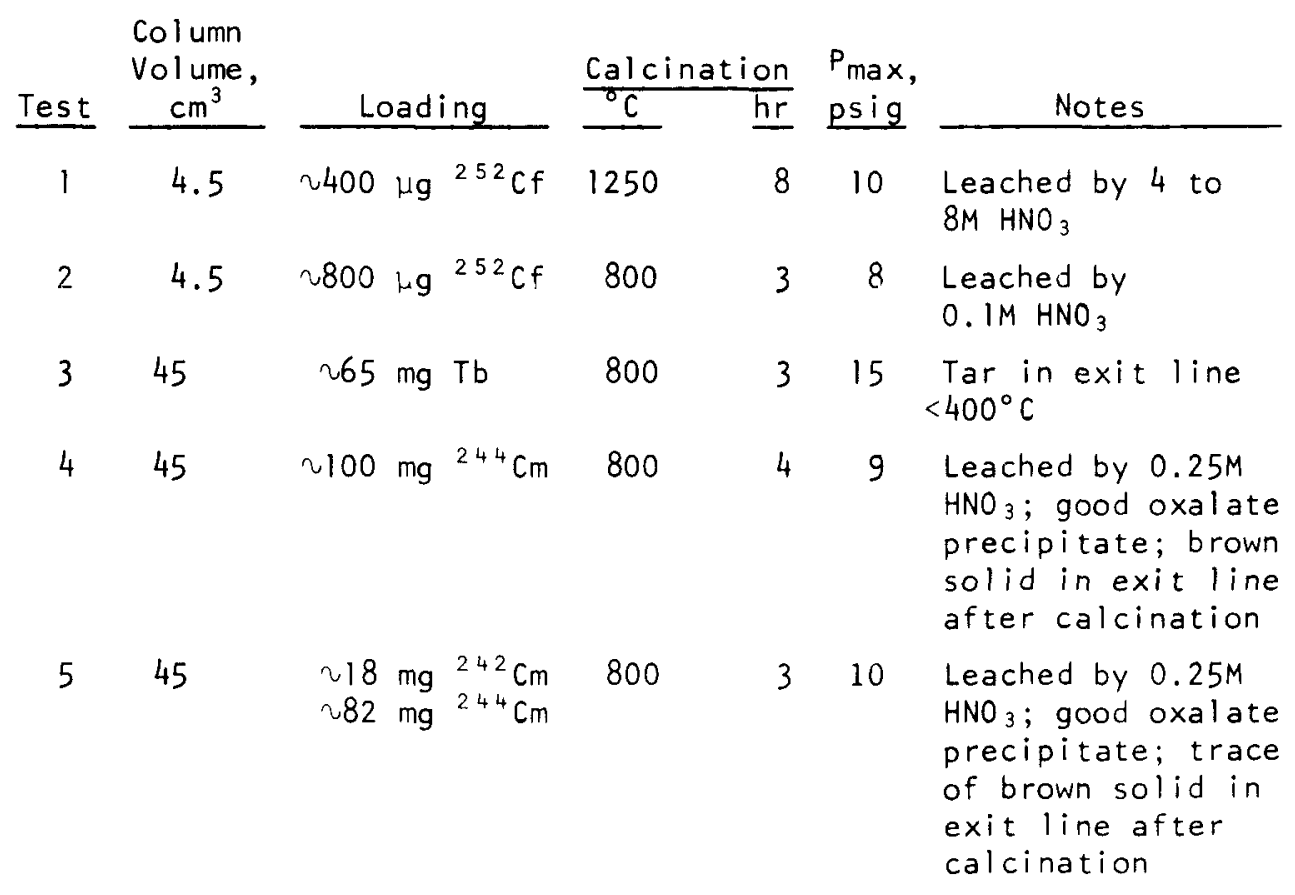

\section{Californium}

${ }^{252} \mathrm{Cf}$ was loaded on $\sim 4.5 \mathrm{~cm}^{3}$ of resin ( 0.1 prototype scale) because of the small quantity of californium available. Two tests were made: Test 1 with $20.4 \mathrm{mg}$ of ${ }^{252} \mathrm{Cf}$; Test 2 with $\sim 0.8 \mathrm{mg}$. About 1 liter of $0.4 \mathrm{M} \mathrm{AHIB}$ adjusted to $0.25 \mathrm{M} \mathrm{HNO}_{3}$ was loaded on the resin for each test. For all tests described, the resin bed was washed with water after sorption and then air dried by vacuum aspiration. 
The column in Test 1 was maintained at $1250^{\circ} \mathrm{C}$ for 8 hours to produce californium oxide. The column in Test 2 was heated to $800^{\circ} \mathrm{C}$, as described for the stainless steel column tests, and was held at $800^{\circ} \mathrm{C}$ for 3 hours to produce californium oxysulfate.

The oxide in Test 1 did not dissolve completely with $0.1,0.5$, or $1 \mathrm{M} \mathrm{HNO}_{3} ; 4 \mathrm{M}$ followed by $8 \mathrm{M} \mathrm{HNO}_{3}$ was used for complete dissolution. A total of $80 \mathrm{ml}$ of acid was used. Because such a small quantity of californium was processed, the cationic impurities in the feed for the test were eight times the total californium, and this may have caused more difficult dissolution. The oxysulfate in Test 2 was dissolved completely from the column with $\sim 47 \mathrm{~m} 1$ of $0.1 \mathrm{M} \mathrm{HNO}_{3}$; $\sim 95 \%$ of the oxysulfate was in the first $10 \mathrm{~m} 1$.

The dilute nitric acid solution from the oxysulfate dissolution ( $2800 \mu \mathrm{g}{ }^{252} \mathrm{Cf}$ ) was precipitated as californium oxalate; $>90 \%$ of the californium precipitated. Precipitation is normal at this concentration when no carrier is used. Filtration was satisfactory. The strong nitric acid product from dissolution of the oxide $\left(\sim 400 \mu \mathrm{g}{ }^{25} \mathrm{Cf}\right.$ ) was processed through chemical separations to yield feed for medical source preparation by electrodeposition.

Terbium Stand-In

Terbium was used as a stand-in for californium in Test 3 because its elution position in elution development chromatography with AHIB is quite similar to that of californium. Nonradioactive cation impurities commonly occur when processing californium; $65 \mathrm{mg}$ of terbium were added to the feed for a full-scale elution development chromatography test using $0.4 \mathrm{M} \mathrm{AHIB}$ at $\mathrm{pH} 3.6$. Flow rates, temperature, and all conditions for the plant were duplicated, except terbium was substituted for californium. The terbium was collected

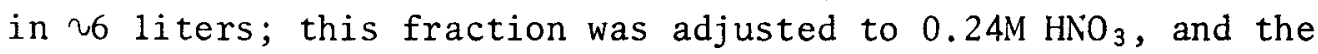
terbium was loaded quantitatively on the $245-\mathrm{ml}$ bed of "Dowex" $50 \mathrm{~W}-\mathrm{X} 8,50$ - to $100-\mathrm{mesh}$ resin at a flow of $\sim 50 \mathrm{ml} / \mathrm{min}$. The bed was washed with water after sorption, dried for 30 minutes, and ignited using the same temperature conditions as Test 2. Air flow was 1 liter/minute. Ignition temperature and pressure behavior were similar to tests with stainless steel columns.

Pyrolysis tar collected in the exit line from the system because this line was not maintained above $400^{\circ} \mathrm{C}$ during calcination. The tar interfered with the dissolution of the terbium oxysulfate; the product contained appreciable soluble and insoluble organic compounds. The terbium product contained $\sim 25 \mathrm{wt} \%$ cationic impurities, mostly zinc and sulfur (oxysulfate) with minor amounts of iron, nickel, chromium, silicon, aluminum, and lead. No platinum was detected. Precipitation of terbium oxalate was not attempted 
because of the tar. This test confirmed that all parts of the system which contact the dissolved product must be kept above $400^{\circ} \mathrm{C}$ during calcination.

\section{Curium}

There were two tests made with curium as a stand-in for ${ }^{252} \mathrm{Cf}$. Test 4 was made with $\sim 100 \mathrm{mg}$ of ${ }^{244} \mathrm{Cm}$, and Test 5 was made with a mixture of $\sim 18 \mathrm{mg}$ of ${ }^{242} \mathrm{Cm}$ and $\sim 82 \mathrm{mg}$ of ${ }^{244} \mathrm{Cm}$. In Test 5 , the mixture of curium isotopes simulated both the mass and the nuclear energy ( $\sim 2.5$ watts) expected for ${ }^{252} \mathrm{Cf}$. In Test $4, \sim 100 \mathrm{mg}$ of ${ }^{24} \mathrm{Cm}$ was loaded quantitatively from AHIB onto the resin by displacement with dilute nitric acid. Calcination conditions were similar to Test 3 except the column and contents were held at $800^{\circ} \mathrm{C}$ for 4 hours. The resin ignited at $<400^{\circ} \mathrm{C}$. Less than $0.01 \%$ of the curium was found in the exit lines, trap, and submicron off-gas filter after the calcination. More than $98 \%$ of the curium was removed from the column with $200 \mathrm{ml}$ of $0.25 \mathrm{M} \mathrm{HNO}_{3}$; the exit line was heated to $\sim 400^{\circ} \mathrm{C}$ during calcination, and no tar was seen in the product solution. More than $99 \%$ of the curium was precipitated from the dilute nitric acid solution when it was adjusted to $0.3 \mathrm{M}$ $\mathrm{H}_{2} \mathrm{C}_{2} \mathrm{O}_{4}$. The total cationic impurities were $<25$ wt $\%$ of the curium in the solution from the column and $<10 \mathrm{wt} \%$ in the solution from the dissolved curium oxalate. No platinum was detected.

A small amount of a finely divided orange-brown solid, which was only slightly soluble in strong nitric acid, was found in the exit frit and line after the ignition. The solid contained very little curium. Spark source mass spectrometry showed mainly iron and oxygen with smaller amounts of nickel, calcium, copper, aluminum, and silicon and traces of platinum, lead, cadmium, tin, chromium, and rhodium in the solid.

In Test 5, the mixture of curium isotopes was sorbed quantitatively from AHIB solution onto the resin by displacement with dilute nitric acid; pressure drop across the resin bed did not increase during the 26 hours of loading. A thermocouple against the column near the top of the resin showed an equilibrium temperature of $\sim 37^{\circ} \mathrm{C}$ after loading was complete and most of the liquid was removed.

Temperature measurements indicated that most of the curium was sorbed on $\sim 10 \mathrm{ml}$ of resin. Storage of the column for $\sim 3$ days before calcination did not affect the pressure drop during calcination at air flow of 1 liter/minute.

The resin was calcined as in previous tests, except that the resin ignited at $\sim 300^{\circ} \mathrm{C}$ (Figure 13) rather than 400 to $450^{\circ} \mathrm{C}$. The lower ignition temperature probably results from variation in batches of resin, although an effect attributable to resin degradation and higher resin temperature because of the curium load cannot 


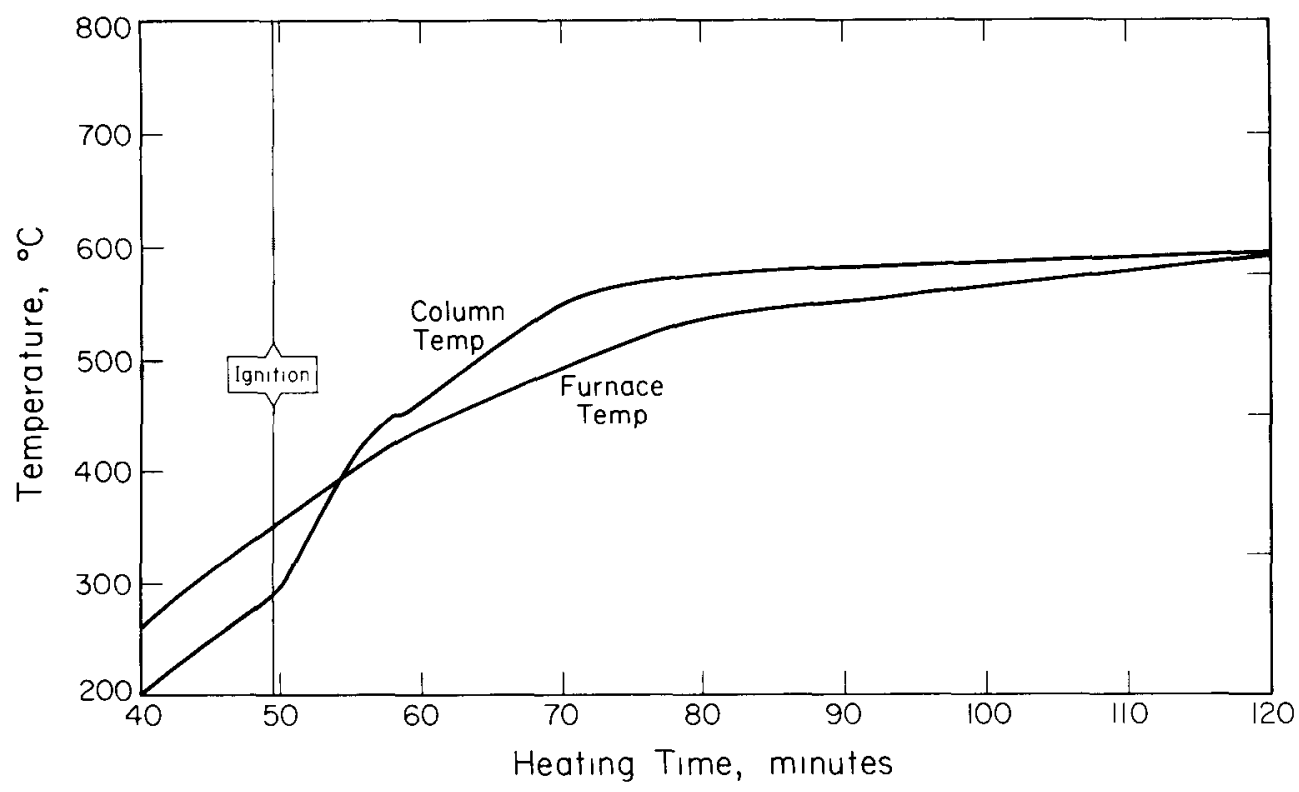

FIGURE 13. Calcination of $2{ }^{24} \mathrm{Cm}-{ }^{244} \mathrm{Cm}$ in Resin

be precluded. Less than $0.01 \%$ of the curium was found in the exit lines, trap, and submicron off-gas filters.

After calcination for $\sim 3$ hours at $800^{\circ} \mathrm{C}, 98 \%$ of the curium was dissolved from the column with $\sim 300 \mathrm{ml}$ of $0.25 \mathrm{M} \mathrm{HNO}_{3}$ and precipitated with oxalic acid. Total cationic impurities were <15 wt \% of the curium; however, the original feed was a simulated solution prepared from reagent chemicals. No platinum was detected. The column was opened after dissolution of the curium and found to contain only a barely visible insoluble brown deposit near the exit. This deposit, which was also seen in some of the previous tests with platinum columns, was free of product.

\section{PRODUCT REMOVAL AND PURITY}

After calcination, the oxysulfate product is dissolved and rinsed from the column with 200 to $300 \mathrm{ml}$ of $0.25 \mathrm{M} \mathrm{HNO}_{3}$ (or $~ 24 \mathrm{M}$ for oxide product). Although not necessary, removal is more effective if the acid is heated.

Filling the volume between the frits with dilute acid for effective dissolution of californium oxysulfate is best accomplished by vacuum transfer of the acid upflow into the column. Filling the column three or four times with dilute acid and allowing each fill to remain in the column $\sim 15$ minutes removes 
$799 \%$ of the californium. Because a small amount of solid was noted between the frits and in the gas exit line after some calcinations, the vacuum should be attached to the exit end of the system, the dilute acid should be added, and the dissolved product should be removed through the inlet end. This permits retention of insoluble solids by the column frits, and the californium nitrate solution will be free of solids. These solids are free of product and are quite insoluble in dilute nitric acid.

No attempt was made to determine purity of products from calcination in stainless steel columns because of the considerable corrosion. The product purity was determined for all tests made in platinum columns, and these data are shown in Table $V$. In general, there were no cationic impurities added during loading and calcination of the resin column; however, there was not appreciable separation attained from cationic impurities present in the feed. The total quantity of impurities is essentially dependent on the volumes of process solution and the previous process steps. The relatively high weight percent of impurities in the californium products (Tests 1 and 2 ) is due to the small quantity of californium used in these tests.

Based on these tests the weight percent impurities in a $\sim_{100} \mathrm{mg}$ batch of product is expected to be $225 \%$, which is well below the 400 wt \% limit acceptable for most applications.

TABLE $\forall$

Product Purity

\begin{tabular}{|c|c|c|c|c|}
\hline \multirow[b]{2}{*}{ Test } & \multirow[b]{2}{*}{ Product } & \multirow{2}{*}{$\begin{array}{l}\text { Impurity in } \\
\text { Product, wt } \% \\
\end{array}$} & \multicolumn{2}{|c|}{ Impurities } \\
\hline & & & Major & Minor \\
\hline 1 & $0.4 \mathrm{mg}^{252} \mathrm{Cf}$ & $\sim 800$ & $\mathrm{Fe}, \mathrm{Zn}, \mathrm{Ca}, \mathrm{S}, \mathrm{Na}$ & $\mathrm{Ni}, \mathrm{Cr}, \mathrm{Si}, \mathrm{Ba}, \mathrm{Pb}$ \\
\hline 2 & $0.8 \mathrm{mg}{ }^{252} \mathrm{Cf}$ & $\sim 600$ & $\mathrm{Fe}, \mathrm{Zn}, \mathrm{Ca}, \mathrm{S}, \mathrm{Na}$ & $\mathrm{Ni}, \mathrm{Cr}, \mathrm{Si}, \mathrm{Ba}, \mathrm{Pb}$ \\
\hline 3 & $265 \mathrm{mg} \mathrm{Tb}$ & $\sim 25$ & $\mathrm{Zn}, \mathrm{S}$ & $\mathrm{Fe}, \mathrm{Ni}, \mathrm{Cr}, \mathrm{Si}, \mathrm{Al}, \mathrm{Pb}$ \\
\hline 4 & $\sim 100 \mathrm{mg}{ }^{244} \mathrm{~cm}$ & $\sim 25$ & $\mathrm{~Pb}, \mathrm{Fe}, \mathrm{S}$ & $\mathrm{Zn}, \mathrm{Ca}, \mathrm{Si}$ \\
\hline 5 & $\begin{array}{l}\sim 18 \mathrm{mg} 242 \mathrm{Cm} \\
282 \mathrm{mg} 244 \mathrm{Cm}\end{array}$ & $<15^{a}$ & $\mathrm{~Pb}, \mathrm{Fe}, \mathrm{Si}$ & $\mathrm{Zn}, \mathrm{Ca}$ \\
\hline
\end{tabular}

a. Feed was a simulated solution prepared from reagent chemicals except spikes of curium isotopes. 


\section{RECOVERY OF PRODUCT LOSSES}

Loss of californium to the effluent from sorption on cation exchange resin from AHIB solution and loss during ignition of the resin to yield californium oxysulfate were very low in all tests. High losses in the sorption effluent could occur if acid adjustment was omitted or if excess acid was added to the feed. Such losses could be reçovered by readjustment of the acid concentration and recycling the solution through the cation resin bed. Because the plant system is designed so that the effluent passes through a low range $\mathrm{BF}_{3}$ detector, losses resulting from improper feed adjustment would be detected immediately.

The experimental tests demonstrated that product loss from the column during ignition is not significant. Two cases of product loss which could result if the platinum frit failed were investigated to determine a method for recovery. The first case assumed oxysulfate in the exit part of the system along with the water and tar collected in the trap and on the submicron filter, simulating a frit failure after most of the resin had been burned. Oxysulfate was added to the mixture that was leached out of the off-gas system with $6 \mathrm{M}$ nitric acid; the resulting solution was heated to boiling, diluted with water to $0.25 \mathrm{M}$ nitric acid, and fed to the bed of cation exchange resin. The product was sorbed quantitatively on the resin.

The second case assumed partially charred or ignited resin getting into the exit system, simulating a frit failure in the early stages of ignition. Such material was prepared by heating resin containing product to $400^{\circ} \mathrm{C}$. It was not possible to leach or elute the product completely from this residue with strong nitric acid. The product was recovered by heating the residue in air at $\sim 800^{\circ} \mathrm{C}$ to yield the oxysulfate and then dissolving the oxysulfate in $0.25 \mathrm{M}$ nitric acid. 


\section{REFERENCES}

1. R. M. Harbour, W. H. Hale, G. A. Burney, and J. T. Lowe. "Large-Scale Separation of Transplutonium Actinides by Pressurized Cation Exchange." Atomis Energy Reviews (to be published).

2. G. A. Burney and R. M. Harbour. "Separation of Milligram Quantities of ${ }^{252} \mathrm{Cf}$ from Multigram Quantities of ${ }^{244} \mathrm{Cm}$ and ${ }^{243} \mathrm{Am} . "$ Radiochim. Acta 16, 63 (1971).

3. J. T. Lowe, W. H. Hale, and D. F. Hallman. "Development of a Pressurized Cation Exchange Chromatographic Process for Separation of Transplutonium Actinides." Ind. Eng. Chem., Process Des. Develop. 10, 131 (1971).

4. J. C. Copeland and B. B. Cunningham. "Crystallography of the Compounds of Californium." J. Inorg. Nucl. Chem. 31, 733 (1969).

5. R. D. Baybarz. "The Berkelium Oxide System." J. Inorg. Nucl. Chem. 33, 1227 (1971).

6. W. H. Hale, Jr. "Thermal Decomposition of Neodymium-Loaded Cation Exchange Resin." J. Inorg. Nucl. Chem. 33, 1227 (1971).

7. R. D. Baybarz, J. B. Knauer, and J. R. Peterson. "New Encapsulation Techniques for the Fabrication of Californium-252 Neutron Sources." Nuclear Tech. 11, 609 (1971).

8. Chemical Technology Division Annual Progress Report for Period Ending March 31, 1971. USAEC Report ORNL-4682, p. 117, Oak Ridge National Laboratory, Oak Ridge, Tenn. (1971). 